\title{
An Empirical Observe at the Effect of Guerilla Advertising on Clients Buy Choice
}

\author{
K. Ravindran, R.Venkateshkumar
}

\begin{abstract}
The present-day organizations are mostly bothered about gaining customers and their attention also most importantly retaining them for a longer duration. Guerilla marketing is one such marketing technique that makes use of unconventional or unique means of attracting customers. More than investment these techniques are more dependent on the creativity and innovation of the person designing the campaign and executing it. It is a low-cost strategy that helps to attract customers quickly with an element of surprise and buzz. Guerilla marketing has been taken as an independent variable where consumer purchase decision happens to be the dependent variable and its sub dependent variables being loyalty, frequency of buying the same product again and again. Guerilla marketing varies from traditional marketing as it's creative and unique at the same time it allows mass coverage on a large scale by spending the least amount of money on the same. It allows the firms to express their views about the product without putting much money or efforts. This research was more quantitative in nature. The sample size under consideration being 783 at $95 \%$ confidence level. The study proves the point that Guerilla marketing does affect consumer purchase decision and their level of brand awareness.
\end{abstract}

Keywords: consumers, creative, Guerilla marketing, strategy, unique,.

\section{INTRODUCTION}

In the present era of heavy competition marketing has become an inevitable for any company irrespective of its size and form. The main aim of any marketing strategy is to attract and retain the customers and make them purchase their products. It may sound easy and simple but practically it is very difficult because of the variety of options available to the customers. Henceforth companies are at a compulsion to come with marketing and advertising strategies that teach the targeted customers and also become a motivational incentive such that they don't think about the others options available around them. There are various marketing strategies that help company achieve this objective and one among them is Guerilla marketing.

A company sorting for an economical and budget friendly strategy at the same time one which leaves a huge impact on the minds of the customers then guerilla marketing happens to be the best choice.

In the present era is we see companies marketing and advertising their products a lot of new techniques and approaches are followed in order to reach out to their targeted customers.

\section{Revised Manuscript Received on December 16, 2019.}

* Correspondence Author

*Dr.K.Ravindran, Department of Business Administration, Kalasalingam Academy of Research and Education, Krishnankoil-626126, Virudhunagar, Tamilnadu, India. Email:Kravindranmba5@gmail.com

Mr.R.Venkatesh kumar, Dept of Management studies, Sri vidya mandir Arts \& Science college Uthangari, India. Email:accvenkatesh@gmail.com
Therefore in this huge lot there is a high possibility of most of the companies and their techniques going unnoticed in this ad war. So it is very essential for every company to portray themselves and reach their customers in their own unique and stronger way which looks apart and different from the techniques of their competitors. Guerilla marketing also has become beneficial to both small and medium sized enterprises and global players.

Guerilla marketing is a prominent marketing technique that focuses on low cost unconventional marketing tactics that yield maximum results. There are various variants of guerilla marketing like relationship marketing, real time marketing, expeditionary marketing, one to one marketing and viral marketing which helps to reach the targeted customers easily and effectively.

Guerilla marketing is about creating an impact on the customer's mind through a surprise and creating a considerable amount of social buzz. This form of marketing is good at making a far more valuable impression on the consumers when compared to the traditional form of marketing. The main reason behind this is that guerilla marketing aims to strike the customers at a more personal level.

Developing a guerilla marketing concept and advertisement requires lots of innovativeness and the company has to pool in a completely new concept focusing on the targeted group of customers. The concept must be such that it steals the eyes of the targeted customers and focuses them to think of the product. A unique strategy strengthening the brand having a greater effect on people needs to be put into action.

Objectives:

1. To get an outlook on the entire concept of guerilla marketing

2. To assess how far the people get influenced by guerilla marketing strategies

3. To analyze the impact of guerilla marketing strategies towards customers purchase decision

4. To evaluate the economic benefits of using guerilla marketing strategies

\section{REVIEW OF LITERATURE}

Guerilla Marketing can be perceived as a variant of marketing communication (MC) that has a due impact on all categories of consumers. It is generally initiated for the purpose of gathering consumer attention through various modes such as direct marketing, PR and advertising (Miller 1993). In their continuous desire of satisfying their needs consumers are witnessing a completely newer concept of marketing communication. And the above concept makes use of various tools like newspapers, magazines, TV, radio, billboards and internet in order to grab the attention of the consumers on a 
continuous basis. In most of the companies all these variants of modern marketing are combined into one Integrate marketing communication (IMC). While all of the organizations compete for sustenance it's for the novel advertising method of Guerilla advertising and marketing came to rescue which even resulted within the boom of black markets and faux products (Back et al,2008).

Lun O. and Dr Yazdanifard R(2014) in their research paper titled "Guerilla Marketing: A successful business model for Xiaomi" pointed out the fact that the organizations are moving away from the traditional techniques of marketing, promoting and advertising in order to be unique and different from the rest of the clan. And in their effort to be unique, Guerilla marketing happens to be the best and extraordinary promotional effort and effective course of action for Xiaomi.

Ahmad Nawaz (2014) in his study detailed that guerilla marketing has a prominent influence on the purchase decision of the consumers and is apt for any type of company. Guerilla Marketing happens to be type of marketing techniques that resorts to unconventional promotional efforts that turns a product into brand to be remembered. Another popular variant of guerilla marketing stealth marketing that includes a number of various other techniques like celebrity marketing.

Prasanna D Raju (2013) stated that advertising plays a important role in influencing the consumer purchase behavior. Advertising and marketing modulates the consumer purchase decision by giving them useful data regarding the product through different mediums. Advertising endows the consumers with maximum satisfaction on their purchase decision as they have complete knowledge regarding the product that they have purchased. As without advertisements the consumers end up having only partial knowledge about the products and hence end up getting dissatisfied on their purchase.

Hahiz Muhammad Arshad, 2014 in his studies on consumer buying decision and their interest towards mobile phones revealed the factor that the above two mechanisms or phenomenon were highly affected by advertisements. Promotions in the form of advertisements create a opinion for the customers and in turn influence their purchase decision.

Bwisa SM (2013) conducted a research at Kenya with the assumption that there is a relationship between guerilla marketing and business growth. For the success of the business most of the sellers resorted to word of mouth marketing techniques. WOM is a variant of guerilla marketing and a powerful marketing strategy through which message can be easily delivered to the consumers and accordingly grasp their attention in a short span of time. This strategy also helps to create and retain relationship with the consumers.

One of the best aspect of guerilla marketing is its applicability unlike visual marketing where everything depends upon what we actually see and conceive like the logo, slogan, tagline and image of the product but here in guerilla marketing it is the creativity and uniqueness of the advertisement that helps to attract and lure the new customers as well as retaining the old ones and influencing the buyers to spread word to others (Syrett \& Lammiman, 2003)

The main intent of the paper is to examine the impact of guerilla marketing techniques on the consumer purchase decision and brand awareness. How consumers react to this new and unconventional medium of marketing. The previous literature details the fact that guerilla marketing techniques have a positive and profound impact on not only the purchase behavior but various other factors relevant to business as well.

\section{METHODOLOGY}

Both primary and secondary data used for the study. Primary data was collected by means of questionnaire. Secondary data was taken from published sources like journals, internet, books and articles; analysis has been made on the basis of response received from the respondents The research type involves Descriptive. 783 customers were selected at $95 \%$ confidence level and $0.035 \%$ of margin of error. The data have been collected by using the structured questionnaire with a probability resign of simple random sampling.

\section{RESULTS}

The respondents were asked to explicit their opinion on a 5factor Likert scale. The scores had been assigned as strongly agree (five factors) to strongly disagree (1 point). The preliminary evaluation changed into made using descriptive evaluation.

\section{Figure 1: Structural model - standardized regression weight Factor loadings}

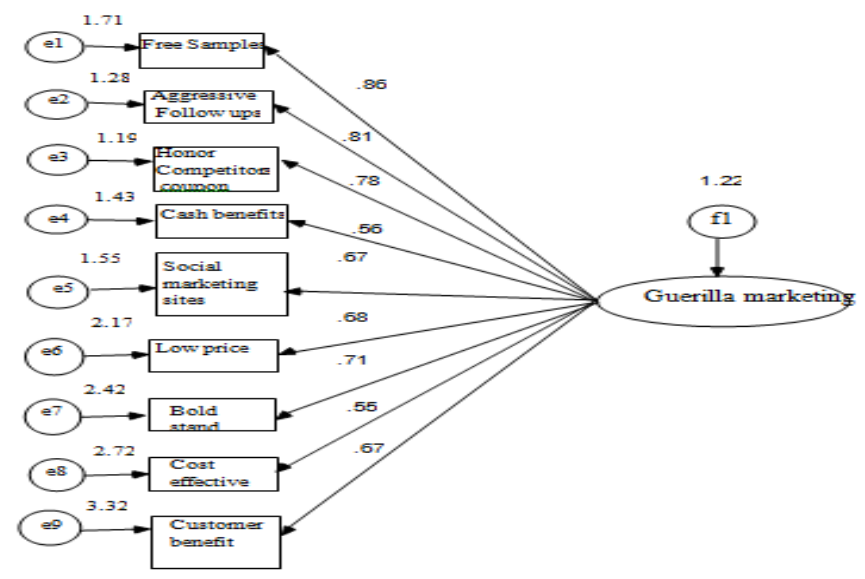

Table 1: Structural model - Covariance relationship estimate

\begin{tabular}{|c|c|c|c|c|c|}
\hline \multicolumn{2}{|c|}{$\begin{array}{c}\text { Covariance relationship } \\
\text { estimate }\end{array}$} & $\begin{array}{c}\text { Beta } \\
\text { estimate }\end{array}$ & $\begin{array}{r}\text { C.R } \\
.\end{array}$ & $\mathrm{P}$ \\
\hline $\begin{array}{c}\text { Free } \\
\text { Samples }\end{array}$ & $--->$ & $\begin{array}{c}\text { Guerilla } \\
\text { marketing }\end{array}$ & .861 & 5.988 & .033 \\
\hline $\begin{array}{c}\text { Aggressive } \\
\text { follow ups }\end{array}$ & $--->$ & $\begin{array}{c}\text { Guerilla } \\
\text { marketing }\end{array}$ & .819 & 8.927 & $* * *$ \\
\hline $\begin{array}{c}\text { Honor } \\
\text { competitor } \\
\text { s coupon }\end{array}$ & $--->$ & $\begin{array}{c}\text { Guerilla } \\
\text { marketing }\end{array}$ & .780 & 6.916 & .021 \\
\hline $\begin{array}{c}\text { Cash } \\
\text { benefits }\end{array}$ & $--->$ & $\begin{array}{c}\text { Guerilla } \\
\text { marketing }\end{array}$ & .560 & 5.348 & $* * *$ \\
\hline
\end{tabular}




\begin{tabular}{|c|c|c|c|c|c|}
\hline \multicolumn{2}{|c|}{$\begin{array}{c}\text { Covariance relationship } \\
\text { estimate }\end{array}$} & $\begin{array}{c}\text { Beta } \\
\text { estimate }\end{array}$ & $\begin{array}{r}\text { C.R } \\
.\end{array}$ & $\mathrm{P}$ \\
\hline $\begin{array}{c}\text { Social } \\
\text { marketing } \\
\text { sites }\end{array}$ & $--->$ & $\begin{array}{c}\text { Guerilla } \\
\text { marketing }\end{array}$ & .674 & 4.564 & .043 \\
\hline Low price & $--->$ & $\begin{array}{c}\text { Guerilla } \\
\text { marketing }\end{array}$ & .686 & 5.399 & $* * *$ \\
\hline Bold stand & $--->$ & $\begin{array}{c}\text { Guerilla } \\
\text { marketing }\end{array}$ & .711 & 6.377 & $* * *$ \\
\hline $\begin{array}{c}\text { Cost } \\
\text { effective }\end{array}$ & $--->$ & $\begin{array}{c}\text { Guerilla } \\
\text { marketing }\end{array}$ & .559 & 7.625 & .032 \\
\hline $\begin{array}{c}\text { Customer } \\
\text { benefit }\end{array}$ & $--->$ & $\begin{array}{c}\text { Guerilla } \\
\text { marketing }\end{array}$ & .677 & 5.114 & $* * *$ \\
\hline $\begin{array}{c}\text { Guerilla } \\
\text { marketing }\end{array}$ & $--->$ & $\begin{array}{c}\text { Customer } \\
\text { purchase } \\
\text { decision }\end{array}$ & .716 & 5.675 & $* * *$ \\
\hline
\end{tabular}

Structural diagram of the analysis presented in Figure 1, depicts the standardized model based on the nine latent variables, free samples, aggressive follow-ups, honor competitor's coupon, cash benefits, social marketing sites, low price, bold stand, cost effective and customer benefits shows the relationship between strategies of guerilla marketing and guerilla marketing. Table 1 represents the results of the Covariance relationship estimate among the latent variables, dependent variable and mediating variable. The critical value, which is more than 1.96 , is considered to be significant (David Garson, 2016).

The critical value of latent variables, free samples (5.958), aggressive follow-ups(8.927), honor competitor's coupon(6.916), cash benefits(5.348), social marketing sites(4.564), low price(5.399), bold stand(6.377), cost effective (7.625)and customer benefits(5.114) have a positive impact with guerilla marketing. Guerilla marketing (5.675) have a positive impact with Customers purchase decision.

Guerilla Marketing is a variant of marketing that originality, creativity and innovation rather than big budgets. Consumers who are bored off with age old traditional methods of advertising and marketing actually react to the new and unconventional mode of marketing. Guerilla marketing by striking the consumers with an element of surprise and creativity in their promotional efforts does leave behind an impact in their mind which is actually long lasting. Guerilla marketing is not different from the traditional marketing mix it's just a modern touch to the age old trend of marketing with and an exciting aspect of surprise to create a buzz is added to that so as to lure new customers as well as retain the existing customers.

Irrespective of the size and form of the organization all of them are resorting to this latest version of marketing in order to be different and to achieve a competitive edge. Guerilla marketing is a dynamic concept at a low budget and mass coverage. Hence it can be concluded stating that guerilla marketing does influence the consumer purchase decision and their brand awareness as through this technique the product becomes a brand quickly and comes to the knowledge of the consumers.

1. Complete expertise in guerilla advertising strategies is needed.

2. Brainstorm the personnel to generate creative and revolutionary thoughts.
3. Encourage and motivate your crew to be able and willing to absorb dangers.

4. Don't just limit the ideas and creativity to paper also execute them properly as required to generate the favored effects

5. Perceive and define target customers.

6. Examine and behavior the required marketplace studies.

7. Estimate the feasible opportunities and for that reason body your realizable objectives.

8. Examine your effects and take the desired movement.

\section{REFERENCES}

1. Nawaz A (2014) Impact of Guerrilla advertisng on Consumer Buying Behavior. Information and Knowledge Management 4: 45-52

2. Bwisa SM (2013) Effects of Guerilla Marketing in Growth of Beauty Shops: Case Study of Matuu Town, Machakos County, Kenya International Journal of Academic Research in Business and Socia Sciences 3: 297-288.

3. Miller J (1993) Marketing Communication. Cornell Hotal and Restaurant Administration 34: 48-53.

4. Prasanna D, Raju V (2013) The Role of Advertising in Consumer Decision Making. IOSR Journal of Business and Management 14: 37-45.

5. Arshad HM, Noor M, Noor N, Ahmad W (2014) Impact of Effective Advertising on Consumer Buying Behavior: A Study of Mobile Phone Purchasers in Pakistan. Journal of Basic and Applied Scientific Research 4: 224-231.

6. Syrett, M., \& Lammiman, J. (2003). Management Development New York: John Wiley \& Sons.

7. Baack, D.W., Wilson, R.T., \& Till, \& B.D. (2008). Creativity and memory effects Recall, Recognition, and an Exploration of Nontraditional Media. Journal of advertising , 37 (4), 85 - 94.

8. Henry, A. (2003). How buzz marketing works for teens. (Vol. 3) Young consumers: Insight and ideas for Responsible Marketers

\section{AUTHORS PROFILE}

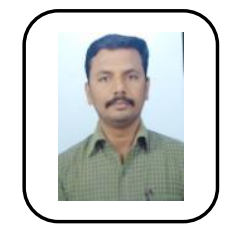

Dr. K. Ravindran MBA., MSW., M,Phil., Ph.D. He has published more than five articles in the UGC listed journals and Scopus indexed journals. He has acting as Guide for Ph.D Programme in Kalasalingam Academy of Research and Education, Virudhunagar District. He has received best teacher award. He has presented more than fifteen papers in the National and International level seminars and conferences organized by Various colleges and universities in India.

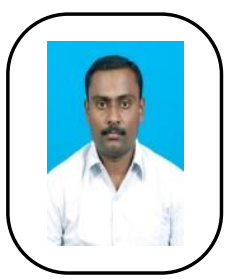

R.Venkateshkumar, $\mathrm{He}$ has persuing $\mathrm{Ph} . \mathrm{D}$ at Periyar University. The author has published more than 5 papers with ISBN Number in National Journals and Presented more than 10 Papers in National and International conferences. Participated more than 15 Seminars and Workshops in various institutions in and around Tamil Nadu. 